\title{
THE AUTHORS' REPLY
}

\section{THE TREATMENT OF CHAGAS DISEASE PATIENTS WITH NITRODERIVATIVE IS UNSATISFACTORY}

\author{
Re: "Persistent infections in chronic Chagas' disease patients treated with anti-Trypanosoma cruzi nitroderivatives" \\ "Then I would still have this consolation - my joy in \\ unrelenting pain - that I had not denied the words”...
}

Brasília, March 3, 2001

Sir,

We are honoured to respond to the "Letter to the Editor", which was signed and forwarded for publication in the current issue of this journal by J. Romeu Cançado. First of all, we would like to praise him for the keen interest to open this important subject for discussion, thus recognizing that the treatment of Chagas disease patients with nitroderivatives is as yet unresolved for many physicians assisting people with this life threatening infectious disease, and for us. With respect to this, we appreciate Cançado's acknowledgment of the merit of our article recently published in this journal ${ }^{6}$, whereas we fully reject his comment that "the results shown do not support the conclusion drawn". On the other hand, we clearly understand Cançado's awareness that there is "controversy concerning the etiological treatment of chronic Chagas Disease, chiefly because there is no consensus for the criterion of cure". This controversy may be explained by lack of randomisation of research protocols, and by different criteria in obtaining data published by several authors in the last three decades. We believe that nitroderivatives may be life saving in those few patients with severe clinical manifestation of acute T. cruzi infection, or in immunosuppressed patients undergoing reactivation of the infection, only. We do not indicate treatment of the chronic $T$. cruzi infections, because we have not found a single benefit resulting from treatment of these Chagas patients with anti-trypanosoma drugs. In conjunction, it holds true that chemotherapy of $T$. cruzi infections with either benznidazole or nifurtimox nitroderivative is unsatisfactory and cannot be recommended since it fails to eradicate the parasite or to change the progression of heart disease in Chagas patients.

Nitroderivatives used for treatment of Chagas Disease: The nifurtimox [4-(5-nitro-phurylideneamino-) tetrahydro-4-4-1, 4-thiazine-1-1-dioxide], and benznidazole [N-benzyl-2-nitro-imidazoleacetamide) are anti-trypanosoma nitroderivatives used to treat $T$. cruzi infections. Severe cytotoxicity has been described for several nitroderivatives, and, in recent decades, these compounds have been shown to possess a variable degree of mutagenic,

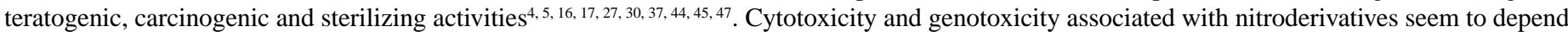
on the binding of electrophilic radicals to macromolecules and DNA, after enzymatic reduction of the nitro-group and generation of free electrophilic radicals, such as nitro-anions, hydroxyl, singlet oxygen and hydrogen peroxide ${ }^{18,21,30,31,41}$. The drug toxicity targets the parasite and the mammalian host cell ${ }^{18,27}$

Effect of treatment of acute and/or recent Trypanosoma cruzi infections: Table 1 shows data from nine research groups of treated acute or recent $T$. cruzi infections in different regions in the American Continent. The success attained by different investigators in this series ranged from $17.5 \%{ }^{38}$, and $20 \%^{36}$ to $76 \%^{10,11}$, and $80 \%^{13}$. However, the investigators in this series of patients have been cautious, for they did not credit the success of the specific chemotherapy to parasitological cure from the T. cruzi infections. This cautiousness might be explained by lack of data from a highly sensitive molecular method $^{6}$, or because data resulting from xenodiagnosis was not shown in 7 out of 9 series; SILVEIRA ${ }^{38}$ and SILVEIRA et al. ${ }^{39}$ reported single series positive xenos were obtained in $18 \%$ of acutely infected and treated patients. Furthermore, claimed success of the chemotherapeutic regime cannot be assumed by seroconversion in 5 out of 9 series of patients, in which serologic data were not shown. In contrast, in three series of patients the serologic assays for T. cruzi infections remained consistently positive in $88.7 \%{ }^{40}, 82.5 \%{ }^{38}$, and $80 \%$ of patients, respectively 4 to 24 years after nitroderivative chemotherapy (Table 1). Of interest, reported data ${ }^{2,40}$ showing spontaneous seroconversion, respectively in $5.5 \%$ to $4.5 \%$ of placebo treated Chagas patients awaits further investigation. These observations need to be considered vis a vis reported success in the nitroderivative treatment of Chagas patients $^{7-11,19,20}$. Furthermore, reported success in treatment of $T$. cruzi infection should be analysed with further caution, because progression of heart lesions in treated patients has been reported on three different occasions ${ }^{3,29,36}$. In two series, the ECG recordings in acutely infected and treated, and in placebo patients were not statistically different, 3 to 4 years after chemotherapy ${ }^{2,40}$. Furthermore, in single series of 40 patients the ECG recordings showed alterations, 24 years after treatment with nitroderivatives ${ }^{39}$. Moreover, in two series of nitroderivative treated acutely $T$. cruzi infected patients, myocardial biopsies displayed myocarditis ${ }^{3,36}$, thus showing that nitroderivative therapy did not prevent severe heart lesions.

Effect of treatment of chronic Chagas disease: A panel of 13 experts from several states in Brazil has set forth the basis for etiological treatment of chronic T. cruzi infections, and advises treatment for recent chronic infections $(<10 \text { years })^{25}$. In practice, the group considered that all children with

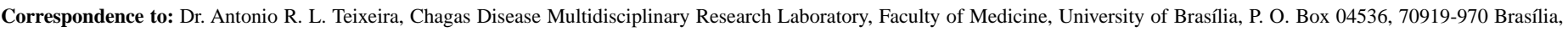
Distrito Federal, Brasil. E-mail: ateixeir@unb.br 


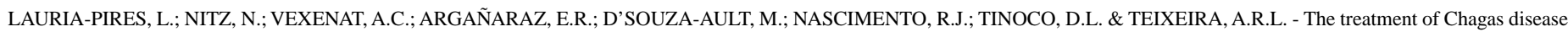
patients with nitroderivative is unsatisfactory. Rev. Inst. Med. trop. S. Paulo, 43(3):175-181, 2001.

positive serological reactions should be treated ${ }^{25}$. Regardless of the results reported after nitroderivative therapy in previous series of acutely infected T. cruzi people shown in Table 1, the decision made was supported only by one fieldstudy showing $55.8 \%$ "cure", three years after nitroderivative chemotherapy $^{2}$. A close examination of this fieldstudy data revealed that those authors observed diminished titers of specific antibodies in $55.8 \%$ of treated children. This observation was mistakenly interpreted as "cure" in the prestigious journal Lancet ${ }^{2}$. In contrast, it seems to us that the data resulting from 11 series of chronic Chagas disease patients shown in Tables 1 and 2 do not support the recommendation by that panel of experts. For example, whereas CANÇADO et al. ${ }^{11}$, reported $76 \%$ of cure of acute Chagas disease patients treated with nitroderivatives, the ratio of cure of chronic Chagas patients treated with the drug reached $8 \%$, after 6 to 18 years of follow-up ${ }^{7-10}$. This latter data is in keeping with FERREIRA ${ }^{20}$, who showed $8 \%$ of sustained seroconversion in nitroderivative treated chronic Chagas patients in the same time span. SILVEIRA ${ }^{38}$ and SILVEIRA et al..$^{39}$ reported $17.2 \%$ of cure after nitroderivative therapy of chronic Chagas patients showing decreasing titers of specific antibodies in three different serologic tests. However, if one considers those low titers as positive instead of negative, those seropositivities reach $94.7 \%$ in treated patients. Therefore, therapeutic success as measured by seroconversion was limited to $5.3 \%$. Consistently, COURA et al. ${ }^{14}$, showed $11.4 \%$ positive xenodiagnosis and $100 \%$ positive serology in 53 chronic Chagas disease treated with nitroderivatives. Furthermore, none of the authors in those remaining 8 series of nitroderivative treated chronic Chagas patients shown in Table 2 revealed the percentage of cure or limited success stemming out of the specific chemotherapy of chronic Chagas disease patients. In addition, CATALIOTI \& ACQUATELLA ${ }^{12}$ showed that mortality was not significatively different in groups of treated and untreated $T$. cruzi infected patients, six years after nitroderivative chemotherapy.

LAURIA-PIRES et al. $^{32}$ treated 45 chronically infected $T$. cruzi patients and compared the progression of Chagas heart disease in this group with that of 46 untreated patients paired by age and gender. The humoral antibodies titers shown by immunofluorescence, hemagglutination, and ELISA assays tended to increase with chronicity of the infection, and cell mediated immunity in chronic Chagas patients was elicited against the $T$. cruzi T12E antigen, regardless of treatment. Moreover, the levels of parasitemia determined by quantitative PCR were not significatively different in both groups of patients ${ }^{6,32}$.

LAURIA-PIRES et al. $^{32}$ performed multiple ECGs, and Holter-type $24 \mathrm{hr}$ recordings for assessments of morbidity in 43 treated and 46 untreated chronic Chagas disease patients, and in 41 uninfected controls. ECG alterations were recorded several-fold more frequently in groups of Chagas patients, whether or not they had been treated, than among uninfected control subjects, and the differences among these proportions were statistically significant $(\mathrm{p}<0.001)$. Interestingly, the Mantel-Haenszel statistical analysis of ECG alterations, recorded one and ten years thereafter, showed highly significant differences in treated as well as in untreated Chagas patients in relationship to uninfected controls. However, the frequencies of ECG alterations in treated and untreated Chagas patients were not statistically distinct $(\mathrm{p}>0.05)$. Moreover, those frequencies were subjected to general association test and revealed lack of statistical significance $(\mathrm{p}=0.19)$. Furthermore, an increasing frequency of ECG alterations was recorded in untreated Chagas patients, ranging from $67.4 \%$ to $75 \%$ over a ten-year period, not being statistically different $(p=0.5)$ from those registered among treated Chagas patients (79\% to $80.5 \%$ ), over the same time span. In this study, Holter-type $24 \mathrm{hr}$ ECG recordings revealed ventricular arrhythmias in $69.6 \%$ of treated Chagas patients, in $58.3 \%$ of untreated Chagas patients, and in $23.5 \%$ of uninfected control subjects (Table 3 ). The differences between proportions observed in treated and untreated Chagas patients are not statistically significant $(\mathrm{p}>0.5)$. However, the differences in proportions between the former groups and the control group are highly significant $(\mathrm{p}<0.001)$. Furthermore, four treated $(9 \%)$ and three untreated $(6.5 \%)$ patients died during the 10-year period of clinical observation. In summary, this study showing lack of a single finding of clinical improvement could not associate a clear benefit of chemotherapy.

Caveat emptors: A major difficulty in obtaining full compliance of the physician's prescription of a nitroderivative to treat $T$. cruzi infected patient appears to be related to toxicity, which prevents the drug intake for recommended period of time. In the series reported by LAURIA-PIRES et al. ${ }^{32}$, records in the files of Chagas disease patients registered various severe side effects after the administration of nitroderivatives to Chagas patients, such as headache, anorexia, gastric discomfort, visual and mental disturbances, loss of libido, dermatitis, peripheral neuropathy, seizures and weight loss that precluded some patients taking the drug for 60 days. Probably as a consequence or the severe side effects, $35.7 \%$ of those patients took the dose of nifurtimox for less than 30 days. Benznidazole produced fewer side effects and $70 \%$ of the patients took the drug dose for 60 days. Under experimental conditions, apathy, ataxia, spastic tetraplegia with hyperreflexia of stretching reflexes, balance disorders, asymmetrical gait, and electroencephalographic alterations were recorded in mongrel dogs treated with doses of benznidazole ranging from 5 to $40 \mathrm{mg} / \mathrm{kg} / \mathrm{day}{ }^{22,23}$. These latter alterations are suggestive of encephalopathy with multifocal characteristics. Histopathologically, these alterations correlated with various types of lesions affecting the meninges, cerebral cortex, hemisphere white matter and subcortical gray matter, brain stem, cerebellum and the spinal cord ${ }^{23}$.

A second caveat is the lack of account for the duration of time patients effectively took the drug per os as outpatients in most of the series described in Tables 1 and 2. In the series reported by LAURIA-PIRES et al. ${ }^{32}, 20$ patients (45\%) completed full treatment for 60 days, 14 (31\%) ingested the drug for at least 30 days, and 11 patients (24\%) received the nitroderivative for at least 20 days. However, a common feature in those studies shown in Tables 1 and 2 is probably a lack of randomization of clinical trial protocols aiming at treatment of Chagas disease. Although there is a possibility that a few acutely infected in-patients took the drug exactly as prescribed, there is a lack of information about how long the bulk of treated Chagas patients complied with full prescription (5 to $10 \mathrm{mg}$ per day for 30 to 60 days). However, this common feature associated with clinical trials of nitroderivatives for treatment of Chagas disease, which is present in each of those 20 series cited in Tables 1 and 2, may not explain the treatment failure.

Effects resulting from the injection of nitroderivative in rabbit: To determine whether the failure of chemotherapeutic regime was associated to the administration of nitroderivatives via oral route in Chagas patients we looked at the results of previous experiments ${ }^{42,43}$, which reported the effect of 


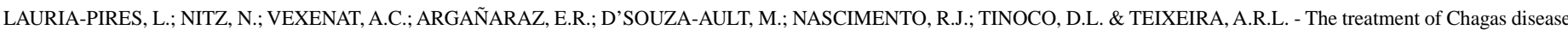
patients with nitroderivative is unsatisfactory. Rev. Inst. Med. trop. S. Paulo, 43(3):175-181, 2001.

Table 1

Effect of oral administration of nitroderivatives to patients with acute or recent Trypanosoma cruzi infections*

\begin{tabular}{|c|c|c|c|c|c|c|c|}
\hline \multirow[t]{2}{*}{ Authors/years } & \multirow{2}{*}{$\begin{array}{l}\text { Number } \\
\text { of patients }\end{array}$} & \multicolumn{6}{|c|}{ Follow-up } \\
\hline & & $\%$ cure & $\begin{array}{l}\text { Duration } \\
\text { (Years) }\end{array}$ & $\begin{array}{c}\text { Pos } \\
\text { Xeno+ }\end{array}$ & $\begin{array}{c}\text { Pos } \\
\text { Serology }\end{array}$ & $\begin{array}{c}\text { ECG } \\
\text { alteration }\end{array}$ & $\begin{array}{l}\text { Pos } \\
\text { PCR }\end{array}$ \\
\hline $\begin{array}{l}\text { Cançado et al., } 1979^{11} ; \\
\text { Cançado, } 1980^{9} ; \\
\text { Cançado, } 2000^{10}\end{array}$ & Treated $=21$ & $76 \%$ & 13 to 21 & & & Normal & ND \\
\hline Ferreira, $1988^{19}$ & Treated $=25$ & 70.0 to $46.6 \%$ & 3 to 23 & & & & ND \\
\hline Cerisola et al., $1975^{13}$ & Treated $=76$ & $80.0 \%$ & 1 & & & & ND \\
\hline Andrade et al., $1996^{2}$ & $\begin{array}{l}\text { Treated }=64 \\
\text { Placebo }=65\end{array}$ & $55.8 \%^{f}$ & 3 & & $44.2 \%$ & $\begin{array}{l}1.7 \\
6.9\end{array}$ & ND \\
\hline Sosa-Estani et al., $1998^{\varphi, 40}$ & $\begin{array}{l}\text { Treated }=55 \\
\text { Placebo }=51\end{array}$ & & 4 & $\begin{array}{l}4.7 \% \\
51.2 \%\end{array}$ & $\begin{array}{l}88.7 \% \\
95.4\end{array}$ & $\begin{array}{l}2.5 \% \\
2.4 \%\end{array}$ & ND \\
\hline Parada et al., $1997^{\delta, 36}$ & Treated $=58$ & & 8 & & $80 \%$ & & ND \\
\hline Freilij \& Altchech, $1998^{26}$ & Treated $=45$ & $34.7 \%$ & 2 to 4 & & & & ND \\
\hline Aires, $1999^{f, 1}$ & $\begin{array}{l}\text { Treated }=53 \\
\text { Placebo }=46\end{array}$ & $84.7 \%$ & 6 & & & & ND \\
\hline $\begin{array}{l}\text { Silveira et al., } 2000^{39} \text {; } \\
\text { Silveira, } 2000^{38}\end{array}$ & Treated $=40$ & $17.5 \%$ & 24 & $18 \%$ & $82.5 \%$ & $15.0 \%$ & $35.9 \%$ \\
\hline
\end{tabular}

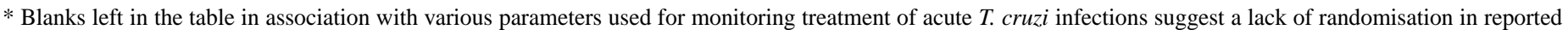

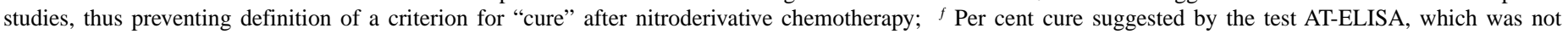

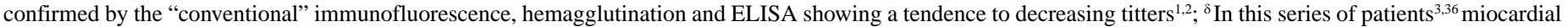

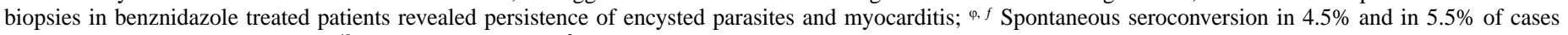
were reported by Sosa-Estani et al. ${ }^{40}$, and of Andrade et al. ${ }^{2}$, respectively.

Table 2

Effect of oral administration of nitroderivatives to patients with chronic Trypanosoma cruzi infections*

\begin{tabular}{|c|c|c|c|c|c|c|c|}
\hline \multirow[t]{2}{*}{ Authors/years } & \multirow{2}{*}{$\begin{array}{l}\text { Number } \\
\text { of patients }\end{array}$} & \multicolumn{6}{|c|}{ Follow-up } \\
\hline & & $\%$ cure & $\begin{array}{c}\text { Duration } \\
\text { (Years) }\end{array}$ & $\begin{array}{l}\text { Pos } \\
\text { Xeno }\end{array}$ & $\begin{array}{c}\text { Pos } \\
\text { Serology }\end{array}$ & $\begin{array}{c}\text { ECG } \\
\text { alteration }\end{array}$ & $\begin{array}{l}\text { Pos } \\
\text { PCR }\end{array}$ \\
\hline $\begin{array}{l}\text { Cançado, 19977; } \\
\text { Cançado, 1999 } \\
\text { Cançado, 200010. }\end{array}$ & $\begin{array}{l}\text { Treated }=113 \\
\text { Placebo }=20\end{array}$ & $8 \%$ & 6 to 18 years & & & & ND \\
\hline Macedo et al., $1984^{33}$ & $\begin{array}{l}\text { Treated }=103 \\
\text { Placebo }=68\end{array}$ & & 7 years & & & $\begin{array}{l}6.7 \\
8.8\end{array}$ & \\
\hline Ferreira, $1990^{20}$ & Treated $=100$ & $8 \%$ & 5 to 18 & $40 \%$ & $92.0 \%$ & 92.0 & ND \\
\hline Ianni et al., $1993^{28}$ & $\begin{array}{l}\text { Treated }=15 \\
\text { Placebo }=18\end{array}$ & & 8 & & & $\begin{array}{l}13.3 \% \\
0 \%\end{array}$ & ND \\
\hline Miranda \& Campos, $1994^{34}$ & Treated $=120$ & & 10 to 16 & & & $10.5 \%$ & ND \\
\hline Viotti et al., $1994^{46}$ & $\begin{array}{l}\text { Treated }=131 \\
\text { Untreated }=70\end{array}$ & & 8 & & $\begin{array}{l}80.9 \% \\
94.0 \%\end{array}$ & $\begin{array}{r}4.2 \% \\
30.0 \%\end{array}$ & ND \\
\hline Fragata et al., $1995^{24}$ & $\begin{array}{l}\text { Treated }=71 \\
\text { Placebo }=49\end{array}$ & & 7 to 8 & & & $\begin{array}{r}7.0 \% \\
14.3 \%\end{array}$ & ND \\
\hline Coura et al., $1997^{14}$ & $\begin{array}{l}\text { Treated }=53 \\
\text { Placebo }=24\end{array}$ & & 1 & $11.4 \%$ & $100 \%$ & & ND \\
\hline $\begin{array}{l}\text { Catalioti \& Acquatella, } \\
1998^{12}\end{array}$ & $\begin{array}{l}\text { Treated }=84 \\
\text { Untreated }=230\end{array}$ & & 6 & & & & \\
\hline Silveira, 2000³ & Treated $=58$ & $17.2 \%$ & 19 & $9.9 \%$ & $94.7 \%^{f}$ & $19.0 \%{ }^{\delta}$ & $34 \%$ \\
\hline Silveira et al., $2000^{39}$. & Placebo $=39$ & & & $44.7 \%$ & $97.4 \%$ & $12.8 \%$ & $57.1 \%$ \\
\hline Lauria-Pires et al., $2001^{32}$ & $\begin{array}{l}\text { Treated }=45 \\
\text { Untreated }=41\end{array}$ & None & 10 & $8.6 \%$ & $100 \%$ & $\begin{array}{l}1.5 \% \\
7.6 \%\end{array}$ & $100 \%$ \\
\hline
\end{tabular}

* Blank spaces left in the table suggest lack of randomisation of the studies, thus preventing definition of a criterion for cure. Pos = positive; $f$ This figure was obtained after addition of cases with positive serologic assays regardless of titers shown; ${ }^{\delta}$ The finding of a higher frequency of ECG alterations in nitroderivative treated patients than in control placebo patients in this series was not explained. 


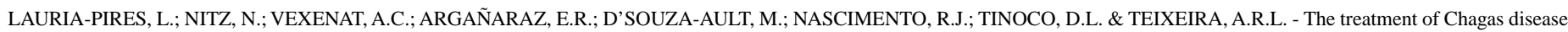
patients with nitroderivative is unsatisfactory. Rev. Inst. Med. trop. S. Paulo, 43(3):175-181, 2001.

the intraperitoneal injections of nitroderivatives in T. cruzi-infected rabbits, and in uninfected rabbits. The dose administered in rabbits was similar to that used to treat Chagas patients: $8 \mathrm{mg} / \mathrm{kg} / \mathrm{day}$, for 60 days. The results of these experiments are shown in Table 4 . The chronic $T$. cruzi infections in rabbits were accompanied by the finding of myocarditis (+ to +++) in every Chagas heart, regardless of treatment. Recently we carried on PCR assays with $T$. cruzi specific kDNA and nDNA nested sets of primers and showed amplification products from Chagas rabbit DNA templates, regardless of treatment. In conclusion, the results of these experiments showed that treatment of $T$. cruzi-infected rabbits with nitroderivatives neither improve the Chagas heart lesions nor prolonged survival of treated animals.

Of interest, malignant lymphomas were consistently seen in $33.3 \%$ of nifurtimox treated rabbits, and in $38.4 \%$ of benznidazole treated rabbits ${ }^{43}$. In contrast, malignant neoplasia was neither seen in the T. cruzi-infected rabbits nor in uninfected, control rabbits. The etiology of chemically induced cancer may involve the covalent binding of the carcinogen to DNA (adducts) leading to mutation in oncogenes or tumor suppressor genes, and ultimately to tumors ${ }^{17,30,44,45,47}$. These formed adducts have the potential to bind covalently to DNA and induce oxidative damage to DNA. Thus growth transformation has been measured by DNA-carcinogen adducts formed by exposure to carcinogenic nitroderivative compounds in model systems and in humans $\mathrm{s}^{37,45,47}$. Figure 1A shows a malignant type non-Hodgkin lymphoma that invades the kidney of a benznidazole treated rabbit. Figure 1B shows interstitial fibrous thickening of the testes and scarcity of germinal cells in the seminiferous tubes of a benznidazole treated rabbit ${ }^{42}$. In conclusion, nitroderivative therapeutic regimes that did not work after oral intake by Chagas patients, also did not work in Chagas rabbits receiving intraperitoneal injections of that dose of the drug used to treat patients. The results of these experiments showed that treatment of $T$. cruzi-infected rabbits with nitroderivatives both neither improve the Chagas heart lesions nor prolonged survival; treated animals developed cancer and died.

Table 3

Frequency of ECG and $24 \mathrm{~h}$ Holter alterations in treated and untreated Chagas' disease patients, and in uninfected control subjects

\begin{tabular}{lccc}
\hline & 1988 & 1998 & 1998 \\
\cline { 2 - 4 } Recordings* $^{*}$ & ECG & ECG & Holter \\
\hline Chagas treated & $34 / 43$ & $29 / 36$ & $23 / 33$ \\
& $(79.0 \%)$ & $(80.5 \%)$ & $(69.6 \%)$ \\
Chagas untreated & $31 / 46$ & $27 / 36$ & $21 / 36$ \\
& $(67.4 \%)$ & $(75.0 \%)$ & $(58.3 \%)$ \\
Uninfected controls & $10 / 41$ & $9 / 40$ & $8 / 34$ \\
& $(24.3 \%)$ & $(22.5 \%)$ & $(23.5 \%)$ \\
\hline
\end{tabular}

- Number of patients with alterations/number of patients tested. Alterations of ECG, and Holter were counted, and the SAS program was used for computer analysis. Differences between alterations were determined by Fisher's exact test. Categorical data showing ECG alterations recorded in two occasions were compared by Mantel-Haenszel chi-square modified after LAURIA-PIRES et al. $^{32}$.
Nitroderivative chronic toxicity in terms of tumor growths should be measured epidemiologically for several years, because nifurtimox and benznidazole administered to rabbits resulted in lymphomas in treated animals. Also, the survival rate among 16 patients subjected to benznidazole, for treatment of Chagas disease reactivation, was $57 \%$ after 2 years, compared to $82.4 \%$ among 75 non-Chagas disease heart transplant patients 5 . Interestingly, $37.5 \%$ of heart transplanted Chagas patients developed malignant tumors after a mean follow-up of $25.3 \pm$ 2.1 months in contrast to only $2.7 \%$ of patients in the untreated control group after $34.6 \pm 3.6$ months ${ }^{5}$.

Concluding remarks: The acute $T$. cruzi infection is usually silent, but the ensuing chronic phase carries an enormous potential for morbidity and mortality due to lesions in the heart, the esophagus, and the colon ${ }^{42}$. Moreover, it has been estimated that 18 million people are chronically infected with $T$. cruzi in Latin America ${ }^{35}$. Certainly, all those chronic Chagas disease patients survived the acute phase of the infection without any specific treatment. This observation tells us that only symptomatic

Table 4

Effect of nitroderivative administration to Trypanosoma cruzi-infected and to normal rabbits*

\begin{tabular}{|c|c|c|c|c|}
\hline \multirow[t]{2}{*}{ Rabbit } & \multirow[t]{2}{*}{ T. cruzi inoculum } & \multicolumn{2}{|c|}{ Histopathological findings } & \multirow{2}{*}{$\begin{array}{c}\text { Survival }^{f} \\
\text { (days after treatment) } \\
(\text { means } \pm \text { SD })\end{array}$} \\
\hline & & Myocarditis** & Neoplasia & \\
\hline Group A $(n=8)$ & Yes & + to +++ & None & $765 \pm 639$ \\
\hline Group B (NF, $n=6)$ & Yes & + to +++ & Lymphoma $(2 / 6)$ & $693 \pm 434$ \\
\hline Group C (NF, $n=6)$ & No & None & Lymphoma $(2 / 6)$ & $723 \pm 414$ \\
\hline Group D $(\mathrm{BZ}, \mathrm{n}=7)$ & Yes & + to +++ & Lymphoma (3/7) & $552 \pm 714$ \\
\hline Group E $(B Z, n=6)$ & No & None & Lymphoma (2/6) & $878 \pm 457$ \\
\hline Group F $(n=12)$ & No & None & None & $1496 \pm 353$ \\
\hline
\end{tabular}

* Two-month old rabbits in experimental groups A, B and D were inoculated with 1 x $10^{6}$ trypomastigotes of T. cruzi per kg body weight. Each rabbit in groups B and $\mathrm{C}$ received daily intraperitoneal injections of $8 \mathrm{mg}$ per $\mathrm{kg}$ of a saline suspension of Nifurtimox (NF) for 60 days. Each rabbit in experimental groups $\mathrm{D}$ and $\mathrm{E}$ received daily intraperitoneal injections of $8 \mathrm{mg}$ per $\mathrm{kg}$ of a saline suspension of Benznidazole (BZ) for 60 days. Control group of twelve rabbits received neither the parasitic infection nor the nitroderivatives; $* *+=$ focal lymphocytic infiltrates and heart cell lysis; $+++=$ diffuse lymphocytic infiltrates heart cell lysis and fibrosis; ${ }^{f}$ Day zero (0) for every experimental and control group was indicated by last day of nitroderivative therapy. Comparison of average survivals: groups A vs B or C, $p>0.50$; groups B or C vs F, $p<0.01$. Groups A vs D or E, $p>0.2$; groups D or E vs F, $p, 0.05$; Data compiled from TEIXEIRA et al. ${ }^{42,43}$. 

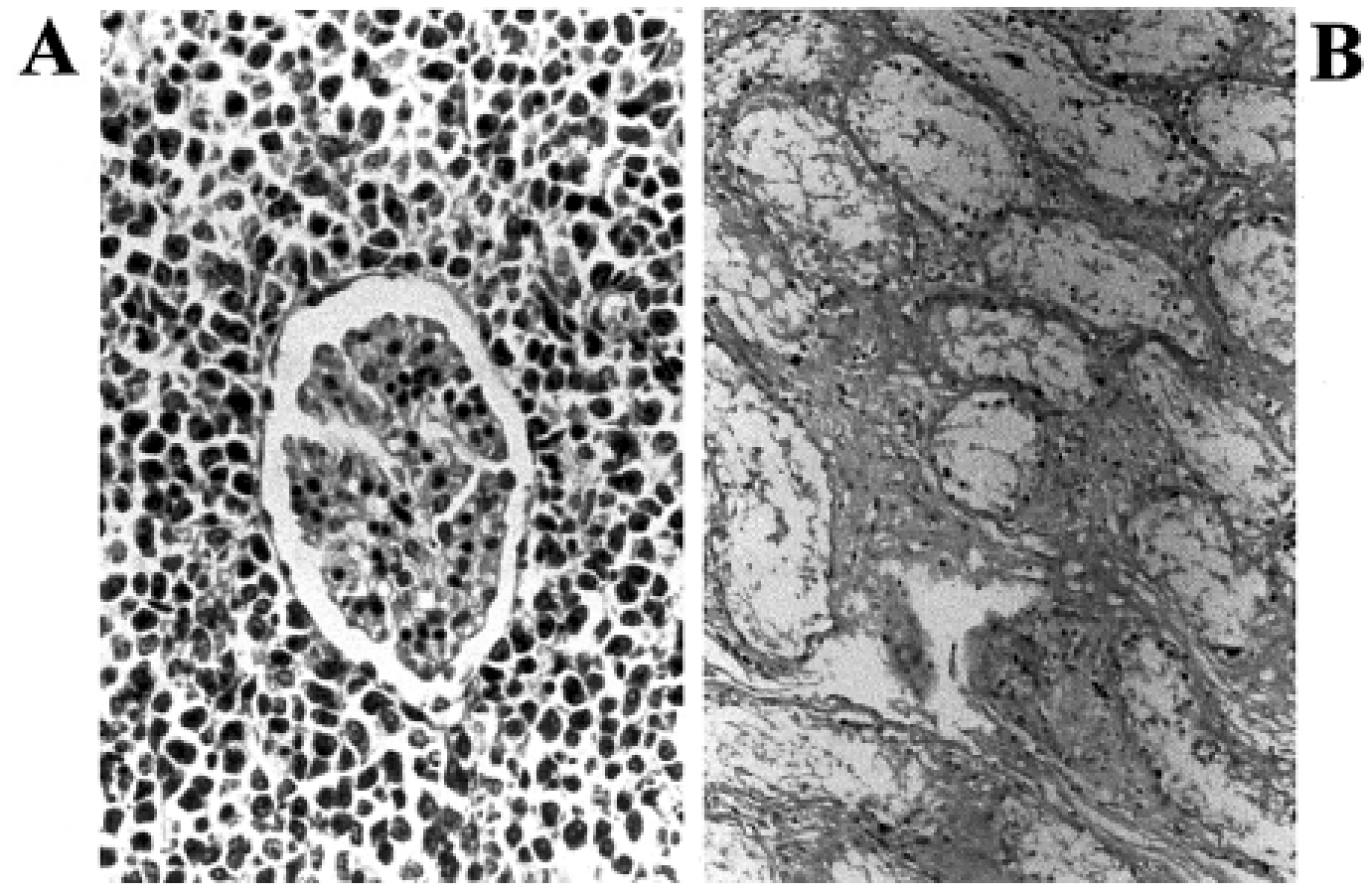

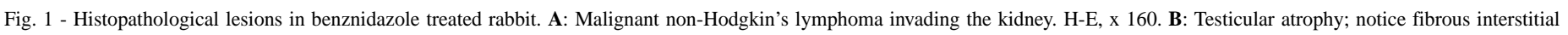
thickening and scarcity of germinal cells in seminiferous tubules. H-E, x 63.

acute Chagas disease patients require nitroderivative therapy. Therefore, we do not recommend treatment for the silent acute infections because the drug brings about cytotoxic and genotoxic effects, and it may not prevent late Chagas lesions in the heart, the esophagus, and the colon. In view of the data discussed here, an effective chemotherapy of $T$. cruzi infections is needed because of the enormous burden chronic infections impose on human populations. Furthermore, an effective chemotherapy for the infection is also highly desirable because it would curtail parasitemia in reservoir hosts, thus preventing peridomestic insect-vector dissemination of the infection in endemic areas.

Meanwhile, we believe that chemotherapy of $T$. cruzi infections with nitroderivative compounds should not be recommended because of the observation of results reported by LAURIA-PIRES et al. ${ }^{32}$, as follows: 1) severe side effects preclude patients older than 20 years of age from complying with full treatment prescribed by physicians; 2) lack of clinical findings showing a benefit of treatment with nitroderivatives; 3 ) lymphoproliferative tumors, such as those described in Chagas patients undergoing heart transplant and benznidazole therapy, can be produced experimentally in rabbits and mice upon injection of either nifurtimox or benznidazole at the dose used to treat human Chagas disease patients, and 4) eradication of the infection appears to be required, in view that decreasing parasitemias did not abrogate humoral and cell-mediated immune responses associated with autoimmunity ${ }^{15}$, and pathogenesis in Chagas disease patients, but this result cannot be achieved by administration of nitroderivatives ${ }^{32}$.

Yours faithfully,

Liana LAURIA-PIRES, Nadjar NITZ,

Ana de Cássia VEXENAT, Enrique R. ARGAÑARAZ, Marian D'SOUZA-AULT, Rubens J. NASCIMENTO

Douglas L. TINOCO \& Antonio R. L. TEIXEIRA.

Chagas Disease Multidisciplinary Research Laboratory. Faculty of Medicine, University of Brasília, Brazil. 
LAURIA-PIRES, L.; NITZ, N.; VEXENAT, A.C.; ARGAÑARAZ, E.R.; D'SOUZA-AULT, M.; NASCIMENTO, R.J.; TINOCO, D.L. \& TEIXEIRA, A.R.L. - The treatment of Chagas disease patients with nitroderivative is unsatisfactory. Rev. Inst. Med. trop. S. Paulo, 43(3):175-181, 2001.

\section{REFERENCES}

1. AIRES, A.I.S. - Eficácia do benznidazol no tratamento de crianças com infecção crônica recente pelo Trypanosoma cruzi. Estudo randomizado, duplo-cego, placebo-controlado com 6 anos de seguimento em área rural sob controle vetorial. 1999. (Tese de Mestrado - Universidade Federal de Goiás).

2. ANDRADE, A.L.S.S.; ZICKER, F.; OLIVEIRA. R.M. et al. - Randomised trial of efficacy of benznidazole in treatment of early Trypanosoma cruzi infection. Lancet, 348: $1407-1413,1996$

3. AÑEZ, N.; CARRASCO, H.; PARADA, H. et al. - Myocardial parasite persistence in chronic chagasic patients. Amer. J. trop. Med. Hyg., 60: 726-732, 1999.

4. ANDRÉ, V.; BOISSANT, C.; LECHEVREL, M. et al. - Mutagenicity of nitro- and amino-substituted carbazoles in Salmonella typhimurium. I. Monosubstituted derivatives of 9 H-carbazole. Mutation Res., 299: 63-73, 1993.

5. BOCCHI, E.A.; HIGUCHI, M.L.; VIEIRA, M.L. et al. - Higher incidence of malignant neoplasms after heart transplantation for treatment of chronic Chagas heart disease. J. Heart Lung Transplant, 17: 399-405, 1998.

6. BRAGA, M.S.; LAURIA-PIRES, L.; ARGAÑARAZ, E.R.; NASCIMENTO, R.J. \& TEIXEIRA, A.R. - Persistent infections in chronic Chagas disease patients treated with anti-Trypanosoma cruzi nitroderivatives. Rev. Inst. Med. trop. S. Paulo, 42: $157-161,2000$

7. CANÇADO, J.R. - Clínica e terapêutica da doença de Chagas: uma abordagem prática para o clínico geral. In: DIAS, J.C.P. \& COURA, J.R., ed. Terapêutica específica da doença de Chagas. Rio de Janeiro, FIOCRUZ, 1997. p. 323-351.

8. CANÇADO, J.R. - Criteria of Chagas disease cure. Mem. Inst. Oswaldo Cruz: 94(supl. 1): 331-335, 1999.

9. CANÇADO, J.R. - Forma aguda da Doença de Chagas no Brasil. Rev. Ass. méd. bras., 26: $285-288,1980$.

10. CANÇADO, J.R. - Tratamento etiológico da Doença de Chagas pelo Benzonidazol. In: BRENER, Z.; ANDRADE, Z. \& BARRAL-NETTO, M., ed. Trypanosoma cruzi e Doença de Chagas. Rio de Janeiro, Guanabara Koogan, 2000.

11. CANÇADO, J.R.; SALGADO, A.A.; BATISTA, S.M. et al. - Specific treatment of human Chagas disease. In: CONGRESSO INTERNACIONAL DE DOENÇA CHAGAS, Rio de Janeiro, 1979. Anais. P2-P5.

12. CATALIOTI, F. \& ACQUATELLA, H. - Comparación de la mortalidad durante seguimento por 5 años en sujetos con enfermedad de Chagas cronica con y sin tratamiento de Benzonidazol. Rev. Pat. trop., 27(supl.): 29-31, 1998.

13. CERISOLA, J.A.; BARCLAY, E.L.; LUGONES, H. \& LEDESMAN, O. - Results of anti Trypanosoma cruzi activity of Ro-7-1051 in man. Chemotherapy, 6: 79-85, 1975.

14. COURA, J.R.; ABREU, L.L.; WILLCOX, H.P. \& PETANA, W. - Estudo comparativo controlado com emprego de benzonidazol, nifurtimox e placebo, na forma crônica da doença de Chagas, em uma área de campo com transmissão interrompida. I. Avaliação preliminar. Rev. Soc. bras. Med. trop., 30: 139-144, 1997.

15. CUNHA-NETO E.; DURANTI, M.; GRUBER, A. et al. - Autoimmunity in Chagas disease: biological relevance of a cardiac myosin-specific epitope cross-reactive to an immunodominant Trypanosoma cruzi antigen. Proc. nat. Acad. Sci. (Wash.), 92: $3541-3545,1995$

16. DEBNATH, A.K.; LOPEZ DE COMPADRE, A.R.; DEBNATH, A.J.; SHUSTERMAN, A.J. \& HANSCH, C. - Structure-activity relationship of mutagenic aromatic and heteroaromatic nitro compounds. Correlation with molecular orbital energies and hydrophobicity. J. medic. Chem., 34: 786-797, 1991.
17. DJURIC, Z.; POTTER, D.W.; CULP, S.J.; LUONGO, D.A. \& BELAND, F.A. - Formation of DNA adducts and oxidative DNA damage in rats treated with 1,6-dinitropyrene. Cancer Lett., 71: 51-56, 1993.

18. DOCAMPO, R.; MASON, R.P.; MOTTLEY, C. et al. - Generation of free radicals induced by nifurtimox in mammalian tissues. J. biol. Chem., 256: 1093-1098, 1971.

19. FERREIRA, H. - Tratamento específico na fase aguda da Doença de Chagas. J. Pediat. (Rio de J.), 64: 126-128, 1988.

20. FERREIRA, H.O. - Tratamento da forma indeterminada da Doença de Chagas com nifurtimox e benzonidazol. Rev. Soc. bras. Med. trop., 23: 209-211, 1990.

21. FERREIRA, R.C.C. \& FERREIRA, L.C.S. - Mutagenicity of nifurtimox and benznidazole in the Salmonella-microsome assay. Braz. J. med. biol. Res., 19: 19-25, 1986.

22. FLORES-VIEIRA, C.L. \& ANTUNES BARREIRA, A. - Experimental benznidazole encephalopathy. I. Clinical-neurological alterations. J. neurol. Sci., 150: 3-11, 1997.

23. FLORES-VIEIRA, C.L.; CHIMELLI, L.; FRANCA FERNANDES, R.M. \& ANTUNES BARREIRA, A. - Experimental benznidazole encephalopathy. II. Electroencephalographic and morphological alterations. J. neurol. Sci., 150: 13-25, 1997.

24. FRAGATA FILHO, A.A.; BOIANAIN, E.; SILVA, M.A.; CORREIA, E.B. \& BORGES FILHO, R. - Validade do tratamento etiológico da fase crônica da doença de Chagas com benzonidazol. Arq. bras. Cardiol., 65 (supl. 1): 71, 1995.

25. FRAGATA FILHO, A.A.; LUQUETTI, A.O.; PRATA, A. et al. - Etiological treatment for Chagas Disease. Parasit. Today, 13: 127-128, 1997.

26. FREILIJ, H. \& ALTCHECH, J. - Respuesta al nifurtimox en pacientes de edad pediátrica con enfermedad de Chagas cronica de la ciudad de Buenos Aires, Argentina. Rev. Pat. trop., 27(supl.): 17-19, 1998.

27. HEADLEY, D.B.; KLOPP, R.G.; MICHIE, P.M.; ERTURK, E. \& BRYAN, G.T. Temporal comparisons of immune status and target organ histology in mice fed carcinogenic 5-nitrofurans and their nornitro analogs. Cancer Res., 41: 1397-1401, 1981.

28. IANNI, B.M.; ARTEOGA, F.; MADY, C. et al. - Uso do benzonidazol em chagásicos na forma indeterminada: resultados a longo prazo. Arq. bras. Cardiol., 61(supl. II): 130-132, 1993.

29. INGLESSIS, I.; CARRASCO, H.A.; AÑEZ, N. et al. - Clinical, parasitological and histopathologic follow-up studies of acute Chagas patients treated with benznidazole. Arch. Inst. Cardiol. Méx., 68: 405-410, 1998.

30. INOUE, M.; KAMIYA, H.; FUJIKAWA, K. et al. - Induction of chromosomal gene mutations in Escherichia coli by direct incorporation of oxidatively damaged nucleotides. New evaluation method for mutagenesis by damaged DNA precursors in vivo. J. biol. Chem., 273: 11069-11074, 1998.

31. KNOX, R.J.; KNIGHT, R.C. \& EDWARDS, D.I. - Interaction of nitroimidazole drugs with DNA in vitro: structure-activity relationship. Brit. J. Cancer, 44: 741-745, 1981.

32. LAURIA-PIRES, L.; BRAGA, M.S.; VEXENAT, A.C. et al. - Progressive chronic Chagas heart disease ten years after treatment with anti-Trypanosoma cruzi nitroderivatives. Amer. J. trop. Med. Hyg., (in press, 2001).

33. MACEDO, V.; SILVEIRA, C.A.N. \& MAUÉS, W.R. - Influência da terapêutica específica na evolução da forma indeterminada da doença de Chagas. Rev Soc. bras. Med. trop., 17(supl.): 34, 1984.

34. MIRANDA, L. \& CAMPOS, G. - História natural da forma crônica da doença de Chagas. Tratamento específico. Rev. Centro Oeste Cardiol., 1: 25-29, 1994. 
35. MONCAYO, A. - Chagas disease.Tropical Disease Research Progress 1991-1992. Eleventh Program Report of the UNDP/World Bank/WHO Special Program for Research and Training of Tropical Diseases (TDR). Geneva,World Health Organization, 1993. p. 67-75.

36. PARADA, H.; CARRASCO, H.A.; AÑEZ, N.; FUENMAYOR, C. \& INGLESSIS, I. Cardiac involvement is a constant finding in acute Chagas disease: a clinical, parasitological and histopathological study. Int. J. Cardiol., 60: 49-54, 1997.

37. QUILLARDET, P.; BOSCUS, D.; TOUATI, E. \& HOFNUNG, M. - DNA damage induced in vivo by 7-methoxy-2-nitronaphto [2,1-b]-furan (R7000) in the lacI gene of Escherichia coli. Mutation Res., 422: 237-245, 1998.

38. SILVEIRA, C.A.N. - Avaliação a longo prazo do tratamento específico da doença de Chagas. Brasilia, 2000. (Tese de Doutorado - Universidade de Brasília).

39. SILVEIRA, C.A.N.; MACEDO, V. \& PRATA, A. - Avaliação a longo prazo do tratamento específico na evolução clínica da forma indeterminada da doença de Chagas. Rev. Soc. bras. Med. trop., 33(supl. II): 36-38, 2000.

40. SOSA-ESTANI, S.; SEGURA, E.L.; RUIZ, A.M. et al. - Efficacy of chemotherapy with benznidazole in children in the indeterminate phase of Chagas' disease. Amer. J. trop. Med. Hyg., 59: 526-529, 1998.
41. TEIXEIRA A.R.L.; CALIXTO M.A. \& TEIXEIRA, M.L. - Chagas disease: carcinogenic activity of the antitrypanosomal nitroarenes in mice. Mutation Res., 305: 189-196, 1994.

42. TEIXEIRA, A.R.L.; CÓRDOBA, J.C.; SOUTO-MAIOR, I. \& SOLÓRZANO, E. Chagas' disease: lymphoma growth in rabbits treated with benznidazole. Amer. J. trop. Med. Hyg., 43: 146-158, 1990.

43. TEIXEIRA, A.R.L.; SILVA, R.; CUNHA-NETO, E.; SANTANA, J.M. \& RIZZO, L.V. Malignant, non-Hodgkin's lymphomas in Trypanosoma cruzi-infected rabbits treated with nitroarenes. J. comp. Path., 103: 37-48, 1990.

44. TOKIWA, H. \& OHNISHI, Y. - Mutagenicity and carcinogenicity of nitroarenes and their sources in the environment. CRC Crit. Rev. Toxicol., 17: 23-60, 1986.

45. TURTELTAUB, K.W.; FRANTZ, C.E.; CREEK, M.R. et al. - DNA adducts in model systems and humans. J. cell. Biochem., 17F(suppl.): 138-148, 1993.

46. VIOTTI, R.; VIGLIANO, C.; ARMENTI, H. \& SEGURA, E. - Treatment of chronic Chagas disease with benznidazole: clinical and serologic evolution of patients with long term follow-up. Amer. Heart J., 127: 151-162, 1994

47. WOLFF, T.; BOGAN, R.; WANDERS, H. \& WEGENKE, M. - Biomonitoring of human exposure to carcinogenic nitroaromatic compounds: a pilot study on DNA adducts formation by 1,6-dinitropyrene in rats. IARC Sci. Publ., 124: 195-199, 1993. 